\title{
Asset Tangibility and Financial Performance: A Time Series Evidence
}

\author{
Yüksel İLTAŞ \\ Kırşehir Ahi Evran Üniversitesi \\ yiltas@ahievran.edu.tr \\ ORCID: 0000-0001-8853-838X \\ Kartal DEMİRGÜNEŞ \\ Kırşehir Ahi Evran Üniversitesi \\ kartal.demirgunes@ahievran.edu.tr \\ ORCID: 0000-0002-6305-0967
}

\begin{tabular}{lrr} 
Araştırma Makalesi & DOI: $10.31592 /$ aeusbed.731079 \\
\hline Geliş Tarihi: 02.05 .2020 & Revize Tarihi: 15.06 .2020 & Kabul Tarihi: 02.07.2020
\end{tabular}

\section{Atıf Bilgisi}

İltaş, Y. ve Demirgüneş, K. (2020). Asset tangibility and financial performance: A time series evidence. Ahi Evran Üniversitesi Sosyal Bilimler Enstitüsü Dergisi, 6(2), 345-364.

\begin{abstract}
Since 1980s, firms' asset investments have more or less tended to shift from tangible to intangible investments. This tendency is also valid for Turkish manufacturing firms. Despite the increasing importance of intangible asset investments, their role on financial performance is subject to considerable debate. These investments are riskier compared to tangible asset investments and cannot easily be used as collateral in corporate borrowing. Tangible assets offering high guarantee are pledged as the primary source of collateral in corporate borrowing. Consequently, a firm with higher asset tangibility is likely to lower external financing costs, leading higher financial performance. This paper analyzes the effect of asset tangibility on financial performance of Turkish manufacturing sector covering 1990.Q3-2016.Q4. The stationarity of series and the cointegration relationship among them are tested by ADF (1979; 1981), KPSS (1992), and Zivot and Andrews (1992) unit root tests, and one-break Gregory and Hansen (1996) cointegration test. Long-run coefficients estimated by Stock and Watson (1993)'s DOLS methodology posit that asset tangibility, financial leverage, liquidity and operating efficiency have significant and positive effects on financial performance till (and including) the break date. However, from this break date on, they affect financial performance negatively.

Keywords: Asset tangibility, financial performance, time series analysis, tangible and intangible assets.
\end{abstract}

\section{Varlık Yapısı ve Finansal Performans Zaman Serisi Bulgusu}

\section{öz}

1980li yılların başlarından itibaren, dünya genelinde firmaların varlık yatırımlarının maddi varlıklardan çok maddi olmayan varlıklara doğru yöneldiği görülmektedir. Bu yönelim Türkiye'deki üretim firmaları için de geçerlidir. Maddi olmayan varlık yatırımlarının öneminin artmasına karşın, bu varlıkların finansal performans üzerindeki etkisi tartışmaya açık bir konudur. Maddi olmayan varlık yatırımları daha riskli olabilmekte ve kaldıraç etkisi yaratmada -maddi- teminat olarak yeterince kullanılamamaktadır. Sonuç itibariyle, maddi varlık yoğun firmaların fonlama maliyetlerinin daha düşük, finansal performanslarının da daha yüksek olması olasıdır. Bu çalışmada; 1990.Q3-2016.Q4 döneminde maddi varlıkların Türk imalat sanayi sektörünün finansal performansı üzerindeki olası etkisi araştırılmaktadır. Serilerin durağanlık düzeyleri ADF $(1979 ; 1981)$, KPSS (1992) ve Zivot ve Andrews (1992) birim kök testleri kullanılarak tespit edilmektedir. Seriler arasındaki uzun dönemli ilişkilerin irdelendiği Gregory ve Hansen (1996) eşbütünleşme testi sonuçları; finansal performans ile maddi varlık yapısı, kaldıraç, likidite ve faaliyet etkinliği arasında uzun dönem ilişkisinin varlığını göstermektedir. Son olarak, uzun-dönem katsayıların tahminlemesinde kullanılan Stock ve Watson (1993)'ın DOLS tahmincisi sonuçlarına göre; maddi varlık yapısı, finansal kaldıraç, likidite ve faaliyet etkinliği değişkenlerinin finansal performansa karşı katsayıları istatistiksel olarak anlamlıdır. Kırılma tarihi (2002.Q1) de dahil olmak üzere, bu tarihe kadar, bağımsız değişkenlerin tamamının finansal performansı olumlu yönde etkilediği görülürken; söz konusu etkileşim kırılma tarihi sonrasında negatife dönmektedir.

Anahtar Kelimeler: Varlık yapıs1, finansal performans, zaman serisi analizi, maddi ve maddi olmayan varliklar.

\section{Introduction}

The Conceptual Framework for Financial Reporting (2018) defines assets as "resources controlled by the entity (i.e. firm, as a type of entity) as a result of past events and from which future 
economic benefits are expected to flow to the entity". For accounting purposes, they are categorized as short-term versus long-term assets, and tangible versus intangible assets. Musah, Kong and Osei (2019) describe tangible assets as physical items of value that are not subject to sale for its customers and are used to generate income. Tangible assets can be classified into two types: (i) current assets -such as cash and cash equivalents, marketable securities, accounts receivable and inventory- with a lifespan of up to one year (short-term) that can easily be converted into cash without loss in value in times of emergency; and (ii) fixed assets -such as property, plant and equipment- for long-term (more than one accounting period) use with relatively low market liquidity (Birch, 2016; Downes and Goodman, 2003). Apart from tangible assets, a firm may have some other long-term operational assets lacking physical substance in contrast to tangible assets. These assets such as patents, copyrights, franchises, licenses, goodwill, software, and trademarks are called as intangible assets and provide firm specific rights. As the market values of these intangible assets are very subjective and difficult to determine, they are usually not shown on the balance sheet until emergence of a situation that requires the value objectively, such as the purchase or sale of an intangible asset.

Over about the last three decades and -especially- since the onset of the global financial crisis of 2007-08, (asset) investment patterns of firms all over the world have more or less tended to shift from tangible to intangible asset investments [Lei, Qiu and Wan (2018) for United States; Thum-Thysen, Voigt, Bilbao-Osorio and Maier (2019) for European Union countries; and Corrado, Haskel, JonaLasinio and Iommi (2016) for Organisation for Economic Co-operation and Development (OECD) countries]. Data derived from the Central Bank of the Republic of Turkey Company Accounts 20052016 also confirms this tendency for Turkish manufacturing firms, though yet the tendency is quite slight. Due to their increasing importance and recognition, intangible assets (i.e. intangible asset investments) have begun to be considered as a critical driver of labor productivity growth (Andrews and Criscuolo, 2013; Andrews and de Serres, 2012; Haskel and Westlake, 2017) and perceived as source of future growth, and a new and potential mechanism to reverse the productivity slowdown observed in many economies after the global financial crisis of 2007-2008 (Andrews, Criscuolo and Pal, 2016).

Despite the increasing importance and necessity of intangible assets in worldwide economies, the rationale behind examining the role of finance for intangible assets and the role of these assets on financial performance is subject to considerable debate. Intangible asset investments are riskier compared to tangible asset investments for several reasons. These assets are generally not traded on open markets due to problems such as imperfect property rights and information asymmetries. Besides, classification and more importantly the valuation of intangible asset investments at firm level is relatively complicated and volatile (Demmou, Stefanescu and Arquie, 2019). In case of bankcrupty, the determination of appraised liquidation value of intangible assets also carries uncertainties due to the fact that they tend to be more firm-specific and not easily transferrable.

One more distinguishing feature of tangible and intangible assets derives from the use of these assets as collateral in corporate borrowing (Bae and Goyal, 2009; Berger and Udell, 1990; Black, de Meza and Jeffreys, 1996; Lei et al., 2018) for data on collateral used in selected countries). Given their characteristics, as compared to tangible assets, it is generally more difficult to finance intangible assets externally; because, due to asymmetry of information in valuation, external investors cannot generally evaluate the feasibility, riskiness and return of the innovative investment projects with required certainty (Himmelberg and Petersen, 1994). Though intangible asset markets have become more liquid over the past three decades according to the Internal Revenue Service (IRS) Reports on Returns of Active Corporations, 1994-2005; and more sophisticated measurement methods for determining the value of intangible assets have been developed, the liquidation value of intangible assets is still significantly lower and unforecastable, causing contracting problems in case of default or bankcrupty (Hart and Moore, 1994).

However, tangible assets offering high guarantee are pledged as the primary source of collateral in corporate borrowing and play an important role in a firm's access to external finance, due to their relatively low asymmetry of information in valuation and high recovery rates (Liberti and Sturgess, 2016; Shleifer and Vishny, 1992). In the presence of frictions such as contract incompleteness and 
limited enforceability, creditors favor tangible assets -though they generally lose value when sold under financial distress (Acharya, Bharath and Srinivasan, 2007), because they can be more easily liquidated in case of bankcrupty (Holmstrom and Tirole, 1997). Besides, the degree of overall asset tangibility is accepted as an indicator of upper bound on a firm's total debt capacity (Dietrich, 2007). As a consequence, a firm with relatively high asset tangibility generally has tendency to lower external financing costs and precautionary savings (Lyandres and Palazzo, 2016); while the one having relatively fewer tangible assets is more likely to face difficulties in raising external capital and be financially constrained missing investment opportunities (Almeida and Campello, 2007).

This paper aims to extend the research on asset tangibility and financial performance nexus providing advanced empirical evidence on a time series data of Turkish manufacturing sector [consisting of Borsa Istanbul (BIST) listed manufacturing firms] for the period of 1990.Q3-2016.Q4. In the following sections, existing literature is summarized and, methodology and empirical results are presented. Finally, the paper is concluded by discussing empirical findings, presenting the limitations of the study and suggesting for further studies.

\section{Literature Review}

Broadly speaking, asset tangibility and financial performance nexus can be discussed by the pecking order theory first suggested by Donaldson (1961) and later modified by Myers (1984), and Myers and Majluf (1984); and the trade-off theory introduced by Kraus and Litzenberger (1973). The pecking order theory contradicts the existence of financial targets stating that firm follows a financing hierarchy. This hierarchy aims to minimize costs due to information asymmetry, and starts with internal resources and continues with external resources. Related to external financing, debt issuance is favored compared to equity issuance due to the lower information cost of debt and adverse selection effect of equity issuance (Demirgüneş, 2016). The pecking order theory considers the effect of tangible assets on capital structure over debt issuance, as these assets can be used as collateral for debt financing. Findings of Almeida and Campello (2007), Campello and Giambona (2013), and Koralun-Bereznicka (2013) confirm that asset redeployability as a determinant of capital structure positively affects access to relatively less costly- debt financing without forcing the firm to issue equity, minimizing overall financing costs and leading higher financial performance.

The trade-off theory predicts the existence of an optimal capital structure of debt and equity (a target debt ratio), where debt tax shields are maximized and bankruptcy costs associated with the debt are minimized. According to Myers (2001), this type of debt financing offers firm a tax shield, as interest accrued on debt can be tax deductible, causing the actual cost of the borrowing to be less than the stated rate of interest. In their own words, Modigliani and Miller (1963) states this advantage of tax shield as; "This means, among other things, that the tax advantages of debt financing are somewhat greater than we originally suggested". In this sense, not exactly the same but as similar to the pecking order theory, trade-off theory also allows firm increase the level of debt financing to gain maximum advantage of tax shield considering increasing riskiness of a possible bankruptcy.

There exists a vast literature focusing on the effect of tangible assets on financial performance. In theory, it can reasonably be expected that a firm with high level of highly liquid assets and tangible assets with high-collateral value is likely to use trade credit (Lu-Andrews and Yu-Thompson, 2015). The liquidation advantage of these assets enables the firm to use trade credit less costly than bank loans. Thus, such a firm is likely to suffer less financial distress, compared to a firm with relatively high level of intangible assets. Tangibility, here, serves as the catalyst leading to reduction in financial distress and improving financial performance.

Empirical studies on the subject offer mixed findings. The empirical findings of Mehari and Aemiro (2013) and Birhan (2017) on insurance companies in Ethiopia confirm statistically significant and positive effect of asset tangibility on financial performance. Besides, findings of Reyhani (2012) and Azadi (2013)'s studies on Tehran Stock Exchange listed manufacturing firms; Dong, Charles and Cai's (2012), Olatunji and Tajudeen's (2014) and Khan, Shamim and Goyal's (2018) papers on Chinese 
corporates, Nigerian commercial banks and National Stock Exchange of India Ltd. (NSE India) listed telecommunication companies, respectively, and Korkmaz and Karaca's (2014) and Kocaman, Altemur, Aldemir and Karaca's (2016) works on manufacturing firms in Turkey also confirm these empirical findings and fit with predictions of the theory on tangible assets and financial performance relationship. However, some empirical findings contradictory to the theory -though outnumbered- also exist. According to the empirical findings of the studies of Eric, Samuel and Victor (2013) on insurance companies in Ghana, Pratheepan (2014) on Colombo Stock Exchange listed manufacturing companies in Sri Lanka, and Vintila and Nenu (2015) on Bucharest Stock Exchange listed firms in Romania, a statistically significant and negative relationship has been confirmed between asset tangibility and financial performance. Lastly, Kotsina and Hazak (2012), Okwo, Okelue and Nweze (2012) and Derbali (2014) have analyzed asset tangibility and financial performance nexus, and have not been able to observe any statistically significant relationship. These mixed empirical findings may be due to the differences in research samples and econometric methodologies used, and in selecting financial performance measures.

\section{Data, Model and Methodology}

This paper aims to analyze the effect of asset tangibility on financial performance by empirical tests including (i) Augmented Dickey-Fuller (ADF, 1981), Kwiatkowski-Phillips-Schmidt-Shin (KPSS, 1992), and Zivot and Andrews (ZA, 1992) unit root tests; (ii) one-break Gregory-Hansen (1996) cointegration test; and (iii) Stock and Watson (1993)'s dynamic ordinary least squares (DOLS) methodology. Before proceeding; sampling, and variable construction, descriptive statistics and research model are reported.

\section{Sampling}

The sample consists of Turkish manufacturing sector with 18 main sectors and 30 sub-sectors from 1990.Q3 to 2016.Q4. The reason to focus on this time window is that the aim of the study is to reveal the effect of asset tangibility on financial performance, by also simultaneous considering the effects of other different firm characteristics such as financial leverage, liquidity and operating efficiency (as control variables); and data integrity available through The Central Bank of the Republic of Turkey (CBRT) web site is limited to the mentioned time window.

\section{Variable Construction, Descriptive Statistics and Research Model}

The left-hand-side variable of the research model is return on assets, a very common profitability measure used as a proxy for financial performance (Charitou, Elfani and Lous, 2010; Falope and Ajilore, 2009; Jose, Lancaster and Stevens, 1996; Saravanan, Sivasankaran, Srikanth and Shaw, 2017; Shin and Soenen, 1998; Şamiloğlu and Demirgüneş, 2008). Profitability is used as a common proxy for financial performance, as it evaluates the efficiency regarding with that tangible assets and net current assets are transformed into profits. Though there are other various financial performance measures such as return on equity which reports the profits earned by the firm for its shareholders (Jose et al., 1996; Wang, 2002); return on invested capital which reports the profits earned by the firm on long-term invested capital (Mohamad and Saad, 2010; Nobanee, Abdullatif and AlHajjar, 2011); gross operating income as the ratio of gross operating profits to total assets (Banos-Caballero, Garcia-Teruel and Martinez-Solano, 2012; Deloof, 2003; Dong and $\mathrm{Su}, 2010$ ) and net operating income as the ratio of net operating profits to total assets (Deloof, 2003), return on assets has some distinctive advantages. It evaluates the efficiency of firm managers in using the firm's real investments and financial resources to generate income (Rivard and Thomas, 1997) and unsimilar to other measures, may be used as a proxy for financial performance in all industries, including manufacturing, financial and non-financial companies (Devi and Devi, 2014; Nunes, Serrasqueiro and Sequeira, 2009).

The main focus of the research model is on asset tangibility. Asset tangibility is mostly defined by two measures in the finance literature as collateral value and tangible assets. Titman and Wessels (1988), and Chang et al. (2009) use the ratio of the inventory plus the gross plant and equipment to total 
assets as a proxy of collateral value in their studies on the determinants of capital structure. On the other hand, tangible assets, also known as fixed assets [or property, plant and equipment (PP\&E)], is a term used in accounting for assets and property with finite monetary value and usually a physical form that cannot easily be converted into cash (Dyckman, 1992), and that are not directly sold to a firm's consumers and/or end-users. Therefore, collateral value measure of Titman and Wessels (1988), and Chang, Lee and Lee (2009) may not be as appropriate as tangible assets to refer asset tangibility, as it also covers inventory as a current asset. According to Rajan and Zingales (1995), tangible asset intensive firms can reduce agency costs of debt due to ease of collateralization of these assets, and reduced agency costs of debt will result in higher financial performance.

There are typically three measures financial leverage as short-term debt to total assets, longterm debt to total assets and total debt to total assets in finance literature. Empirical findings on the effect of leverage on financial performance have yielded mixed results. According to the studies of Stulz (1990), Ang, Cole and Lin (2000), Abor (2007), Güngöraydınoğlu and Öztekin (2011) and Degryse, Goeji and Kappert (2012), there is a positive relationship between financial leverage and financial performance. This can be explained by disciplinarian impact of higher financial leverage on firm managers' cash flow waste (Grossman and Hart, 1982), as higher pressure of leverage (debtholders) on firm may result in increasing financial performance to generate more cash to pay for debt. In contrast, some other empirical studies (Dawar, 2014; De Jong, Kabir and Nguyen, 2008; Hall, Hutchinson and Michaelas, 2004; Mateev, Poutziouris and Ivanov, 2013; McConnell and Servaes, 1995) conclude that financial leverage is negatively related to financial performance. Higher leverage may increase interest payments resulting in less cash availability. Besides, higher leverage may also result in relative increase in interest rates and in need for more collateral (tangible assets), and this may reduce financial performance causing decrease in cash flows.

Liquidity management -as another possible determinant of financial performance- can be linked to working capital management, as most of the measures used to evaluate liquidity are derived from the components of working capital (Demirgüneş, 2016). Thus, literature on the liquidity measures evaluating the effect of liquidity on financial performance is two-fold. While some studies focus on cash conversion cycle; others focus on fundamental liquidity ratios such as current, acid-test and cash ratios. Cash conversion cycle reflects only the operational side of the firm concentrating on accounts receivables, accounts payables and inventories However, liquidity ratios, as more comprehensive measures of corporate liquidity, capture financial aspects of a firm covering current assets and current liabilities (Mun and Jang, 2015). Regarding the empirical findings; Sur, Biswas and Ganguly (2001), Bardia (2004), Eljelly (2004), Narware (2004) and Saldanl1 (2012) conclude that current ratio as a proxy for corporate liquidity has statistically significant and negative effect on financial performance. On the contrary, findings of Ghosh and Maji (2003), Muhammad, Jan and Ullah (2012), Ehiedu (2014) and Rehman, Khan and Khokhar (2015) confirm the positive effect of current ratio on financial performance.

Lastly, accounts receivable turnover ratio as proxy for operating efficiency is included in the model. This ratio is an accounting measure used to quantify a company's effectiveness in collecting its receivables or money owed by clients. Relatively low/high accounts receivable turnover ratios are consequences of firm's liberal/conservative credit policies. Though liberal credit policy has advantages that it stimulates firm's sales due to availability of longer repayment period to customers for product assessment and ease of access to finance for product acquisition; conservative credit policy has a sideeffect of holding excessive working capital investment that eventually lowers return on assets and increases overall risk by destroying firm value (Deloof, 2003). Empirical literature fits for the reflections of these policies. The findings of Dong and Su (2010), Lyngstadaas and Berg (2016), and Shrivastava, Kumar and Kumar (2017) conclude that there is statistically significant and negative relationship between accounts receivable turnover ratio and financial performance; while findings of Ramachandran and Janakiraman (2009), Sharma and Kumar (2011) and Abuzayed (2012) confirm the opposite. Definitions of the variables included in the research model, descriptive statistics and correlation matrix for the data are given in Table 1. 
Table 1

Variable Definitions, Descriptive Statistics and Correlation Matrix for the Data

\begin{tabular}{|c|c|c|c|c|c|}
\hline Descriptive Statistics & $R O A$ & TAN & $L E V$ & $L I Q$ & $O E F$ \\
\hline Mean & 0.045 & 0.597 & 0.519 & 1.466 & 4.167 \\
\hline Median & 0.046 & 0.604 & 0.527 & 1.444 & 4.049 \\
\hline Standard Deviation & 0.033 & 0.068 & 0.058 & 0.135 & 2.137 \\
\hline Minimum & -0.030 & 0.234 & 0.366 & 1.215 & 1.249 \\
\hline Maximum & 0.137 & 0.714 & 0.648 & 2.013 & 13.002 \\
\hline Number of Observations & 108 & 108 & 108 & 108 & 108 \\
\hline Correlation Matrix & $R O A$ & TAN & $L E V$ & $L I Q$ & $O E F$ \\
\hline$R O A$ & 1.00 & & & & \\
\hline$T A N$ & -0.33 & 1.00 & & & \\
\hline$L E V$ & -0.37 & 0.09 & 1.00 & & \\
\hline$L I Q$ & 0.65 & -0.24 & -0.71 & 1.00 & \\
\hline$O E F$ & 0.64 & -0.22 & -0.38 & 0.49 & 1.00 \\
\hline
\end{tabular}

*All sector-level data on Turkish manufacturing sector (consisting of Borsa Istanbul listed manufacturing firms) from 1990.Q3 to 2016.Q4 are obtained from Finnet database. Return on assets (ROA) as a proxy for financial performance is the ratio of net income to total assets. Tangible assets (TAN) as a proxy for asset tangibility is the ratio of tangible assets to total assets. Total debt ratio (LEV) as a proxy for financial leverage is the ratio of total debt (short- and long-term debt) to total assets. Current ratio (LIQ) as a proxy for corporate liquidity is the ratio of current assets to current liabilities. Accounts receivable turnover ratio (OEF) as a proxy for operating efficiency is the ratio of net credit sales to average accounts receivable.

It is important to check the correlation between the independent variables to avoid multicollinearity that refers to the extent to which independent variables are correlated. This should be done before developing the research model. As seen in Table 1, the analysis confirms the non-existence of multicollinearity among the variables, as all Pearson correlation coefficient values are less than the cut-off point of 0.60 .

The regression equation to test relationships between the variables discussed above is as:

$$
R O A_{t}=\beta_{0}+\beta_{1} T A N_{t}+\beta_{2} L E V_{t}+\beta_{3} L I Q_{t}+\beta_{4} O E F_{t}+\varepsilon_{t}
$$

\section{Unit Root Tests}

In order to avoid the spurious regression problem, the order of integration of the variables should be investigated. This study uses the ADF (1981), KPSS (1992), and ZA (1992) unit root tests for detecting the presence of a unit root. ADF test is derived from Dickey-Fuller (hereafter, DF, 1979) test. As one of the mostly used unit root tests, DF test is based on the model of the first-order autoregressive process (Box and Jenkins, 1970).

The test statistic of the ADF test is calculated as:

$$
\Delta y_{t}=\left(\phi_{1}-1\right) y_{t-1}+\sum_{i=1}^{p-1} y_{i} \Delta y_{t-1}+\varepsilon_{t}
$$

The problem of this test is the choice of lags $p$. Schwert (1989) suggests that the maximum lag is $p_{\max }=12\left(\frac{T}{100}\right)^{1 / 4}$, because if $p$ is too low, the test will be affected by autocorrelation and if $p$ is too large, the power of test will be lower (Arltova and Fedorova, 2016).

The limiting distribution of test statistics is identical with the distribution of DF test statistics and for $T \rightarrow \infty$ is tabulated in Dickey (1976) and MacKinnon (1991). 
The unit root tests suggested by DF (1979) and ADF (1981), Phillips and Perron (1988), Elliot, Rothenberg and Stock (1996), Ng and Perron (1995), Ng and Perron (2001) test the null hypothesis that the time series $y_{t}$ is integrated of order one, I(1). However, KPSS (1992) test proposes that the time series is stationary around a deterministic trend and is calculated as the sum of a deterministic trend, random walk and stationary random error.

KPSS test is based on LM test of the hypothesis that the random walk has a zero variance, i.e. $H_{0}: \sigma_{u}^{2}=0$ meaning that $r_{t}$ is a constant, against the alternative $H_{1}: \sigma_{u}^{2}>0$. The test statistics is as:

$$
L M=\frac{\sum_{t=1}^{T} s_{t}^{2}}{\widehat{\sigma}_{\varepsilon}^{2}}
$$

where $s_{t}=\sum_{t=1}^{T} \hat{\varepsilon}_{t}, t=1,2, \ldots, T$, and $\hat{\sigma}_{\varepsilon}^{2}$ is the estimate of variance $\hat{\sigma}_{\varepsilon}^{2}$ of process $\varepsilon_{t}$ from Equation (7). Critical values are derived by a simulation and listed in KPSS (1992).

Major events like economic crises, catastrophes, terrorism and pandemics may have influences on the data analyzed, as they tend to create structural break(s) in the series. Traditional unit root tests such as ADF and KPSS towards finding evidence of non-stationarity in time series analysis may sometimes be biased due to presence of these structural breaks. Therefore, in such cases advanced unit root tests allowing for the presence of structural break(s) are required. These tests prevent the obtained results from being biased towards nonstationarity and unit root and can identify the possible break date (Glynn, Perara and Verma, 2007). Therefore, Zivot and Andrews (1992) unit root test with endogenous structural break is also performed to avoid obtaining biased results.

ZA test, also known as a sequential trend break model, is a variation of Perron (1989)'s original test with their assumption that the exact timing of the structural break point is not known. Instead, they develop a data dependent algorithm as a proxy for Perron (1989)'s subjective procedure to determine the break points. The main difference between these two models is that Perron (1992)'s model is a predetermined break, while ZA is an estimated break. Zivot and Andrews (1992) proceed with three models to test for a unit root: (i) Model A permitting a one-time change in the level of the series; (ii) Model B allowing for a one-time change in the slope of the trend function, and (iii) Model C combining one-time changes in the level and the slope of the trend function of the series. The regression equations corresponding to these models are as:

$$
\begin{aligned}
& \Delta y_{t}=c+\alpha y_{t-1}+\beta t+\gamma D U_{t}+\sum_{j=1}^{k} d_{j} \Delta y_{t-j}+\varepsilon_{t}(\text { Model } A) \\
& \Delta y_{t}=c+\alpha y_{t-1}+\beta t+\theta D T_{t}+\sum_{j=1}^{k} d_{j} \Delta y_{t-j}+\varepsilon_{t}(\text { Model } B) \\
& \Delta y_{t}=c+\alpha y_{t-1}+\beta t+\theta D U_{t}+\gamma D T_{t}+\sum_{j=1}^{k} d_{j} \Delta y_{t-j}+\varepsilon_{t}(\text { Model } C)
\end{aligned}
$$

where $D U_{t}$ is an indicator dummy variable for a mean shift occurring at each possible break date $(T B)$, while $D T_{t}$ is variable for corresponding trend shift.

The null hypothesis for all models is $\alpha=0$, implying that the series $\left(y_{t}\right)$ contains a unit root with a drift that excludes any structural break, while the alternative hypothesis $\alpha<0$ is that the series is a trend-stationary process with a one-time break occurring at an unknown point of time.

\section{Cointegration Test}

The study employs one-break Gregory and Hansen (1996) cointegration test to detect structural break in the cointegrating relationship among variables. This cointegration test can be regarded as an extension of Engle and Granger (1987) approach and it involves testing the null hypothesis of no cointegration against an alternative of cointegration with a single regime shift (structural break) in an unknown date based on extensions of the traditional $A D F, Z_{\propto}$ and $Z_{t}$ test types (Doguwa et al., 2014). 
Gregory and Hansen (1996) propose three models of (i) level shift (C), (ii) level shift with trend $(\mathrm{C} / \mathrm{T})$ and $(\mathrm{iii})$ intercept with slope shifts $(\mathrm{C} / \mathrm{S})$ to test for cointegration with structural breaks as adopted to research model of the study:

$$
y_{t}=\mu_{1}+\mu_{2} \varphi_{t}+\alpha_{1} a_{t}+\alpha_{2} b_{t}+\alpha_{3} c_{t}+\alpha_{4} d_{t}+\varepsilon_{t}(\text { C model })
$$

where $\mu_{1}$ and $\mu_{2}$ represent the intercept before and after the shift, respectively.

$$
y_{t}=\mu_{1}+\mu_{2} \varphi_{t}+\beta_{t}+\alpha_{1} a_{t}+\alpha_{2} b_{t}+\alpha_{3} c_{t}+\alpha_{4} d_{t}+\varepsilon_{t}(C / \text { T model })
$$

where $\beta$ is the coefficient of the trend term, t.

$$
y_{t}=\mu_{1}+\mu_{2} \varphi_{t}+\alpha_{1} a_{t}+\alpha_{11} \varphi_{t} a_{t}+\alpha_{2} b_{t}+\alpha_{22} \varphi_{t} b_{t}+\alpha_{3} c_{t}+\alpha_{33} \varphi_{t} c_{t}+\alpha_{4} d_{t}+\alpha_{44} \varphi_{t} d_{t}+\varepsilon_{t}(C / \text { S model })
$$

where $\alpha_{1}, \alpha_{2}, \alpha_{3}$ and $\alpha_{4}$ denote the cointegrating slope coefficients before the regime shift and $\alpha_{11}, \alpha_{22}, \alpha_{33}$ and $\alpha_{44}$ denote the change in slope coefficients.

Gregory and Hansen (1996)'s test is proposed for testing the cointegration in situations with an unknown break date. Therefore, it requires computing the common statistics (ADF and Phillips test statistics) for all possible break points $(\tau)$ and then selecting the smallest values to determine the most appropriate break dates (Narayan, 2007). This procedure of selecting small values of test statistics potentially constitutes evidence against the null hypothesis of no cointegration. 1996):

Formulations of $\operatorname{ADF}\left(A D F^{*}\right)$ and Phillips test statistics $\left(Z_{t}^{*}\right.$ and $\left.Z_{\propto}^{*}\right)$ are as (Gregory and Hansen,

$$
\begin{aligned}
& A D F^{*}=\inf _{\tau \in T} A D F(\tau) \\
& Z_{t}^{*}=\inf _{\tau \in T} Z_{t}(\tau) \\
& Z_{\alpha}^{*}=\inf _{\tau \in T} Z_{\alpha}(\tau)
\end{aligned}
$$

The critical values calculated can be obtained from Table 1 in Gregory and Hansen (1996). In the case that calculated test statistics are greater than the critical values, there exists a cointegration relationship among the series, rejecting the null hypothesis of no cointegration.

\section{Estimation of Long-Run Coefficients}

After determining the cointegration relationship, the next step is to estimate the long run cointegration coefficients that explain the relationships among the series. This study employs DOLS methodology of Stock and Watson (1993). This methodology is improved on ordinary least squares (OLS) and has certain advantages over both OLS and the maximum likelihood procedures, as it copes with small sample and dynamic sources of bias. As a robust single equation approach, DOLS corrects for endogeneity by the inclusion of leads and lags of the first differences of the regressors, and for serially correlated errors by a generalized least squares procedure (Esteve and Requena, 2006). The DOLS estimator is obtained as:

$$
y_{t}=\alpha_{0}+\alpha_{1} t+\alpha_{2} x_{t}+\sum_{i=-q}^{q} \delta_{i} \Delta x_{t-i}+\varepsilon_{t}
$$

where $q$ and $\varepsilon_{t}$ represent optimum leads and lags, and the error term, respectively. 


\section{Empirical Results}

\section{Results of Unit Root Tests}

Test results of ADF, KPSS and ZA (with break dates given in parentheses) are presented in Table 2. Test results indicate that series are stationary at their first differences and integrated of order one, I(1).

Table 2

Unit Root Test Results of ADF, KPSS and ZA

\begin{tabular}{|c|c|c|c|c|c|c|c|}
\hline \multirow{2}{*}{ Variable } & & \multicolumn{3}{|c|}{ Level } & \multicolumn{3}{|c|}{ First Differences } \\
\hline & & $\mathrm{ADF}$ & KPSS & $\mathrm{ZA}$ & $\mathrm{ADF}$ & KPSS & $\mathrm{ZA}$ \\
\hline \multicolumn{2}{|l|}{$R O A$} & -2.293 & 0.764 & $\begin{array}{c}-4.078 \\
(2001 . Q 1)\end{array}$ & $-4.375 * * *$ & $0.026 * * *$ & $\begin{array}{l}-5.990 * * * \\
(2002 . Q 1)\end{array}$ \\
\hline \multicolumn{2}{|l|}{$T A N$} & -1.761 & 0.567 & $\begin{array}{c}-3.791 \\
(2004 . Q 1)\end{array}$ & $-6.863 * * *$ & $0.146^{* * * *}$ & $\begin{array}{l}-5.444 * * * \\
(2004 . Q 4)\end{array}$ \\
\hline \multicolumn{2}{|l|}{$L E V$} & -2.287 & 0.990 & $\begin{array}{c}-3.841 \\
(2007 . Q 1)\end{array}$ & $-3.691 * * *$ & $0.069 * * *$ & $\begin{array}{c}-11.064 * * * \\
(2003 . Q 4)\end{array}$ \\
\hline \multicolumn{2}{|l|}{$L I Q$} & -2.253 & 1.435 & $\begin{array}{c}-3.982 \\
(2005 . Q 1)\end{array}$ & $-5.142 * * *$ & $0.017 * * *$ & $\begin{array}{l}-5.627 * * * \\
(2005 . Q 1)\end{array}$ \\
\hline \multicolumn{2}{|l|}{$O E F$} & -2.407 & 2.560 & $\begin{array}{c}-3.282 \\
(2003 . Q 2) \\
\end{array}$ & $-7.152 * * *$ & $0.016^{* * *}$ & $\begin{array}{l}-5.605 * * * \\
(2004 . Q 1) \\
\end{array}$ \\
\hline \multirow{3}{*}{ Critical Values } & $1 \%$ & -3.497 & 0.739 & -4.80 & -3.497 & 0.739 & -4.80 \\
\hline & $5 \%$ & -2.890 & 0.463 & -4.42 & -2.890 & 0.463 & -4.42 \\
\hline & $10 \%$ & -2.582 & 0.347 & -4.11 & -2.582 & 0.347 & -4.11 \\
\hline
\end{tabular}

*** implies significance at the $1 \%$ level and denotes rejection of the $H_{0}$.

\section{Results of the GH Cointegration Test}

After the all variables are found to be I(1) by unit root tests, Gregory and Hansen (1996) cointegration test is performed to examine the cointegration relationship. Gregory and Hansen (1996)'s cointegration test results indicating the existence of cointegration relationship among the variables are given in Table 3.

Table 3

Cointegration Test Results of Gregory and Hansen (1996)

\begin{tabular}{llccc}
\hline \multirow{2}{*}{ Model } & \multirow{2}{*}{ Break Date } & \multicolumn{3}{c}{ Test Statistics } \\
\cline { 3 - 5 } & & $A D F^{*}$ & $Z_{t}^{*}$ & $Z_{\alpha}^{*}$ \\
\hline $\mathrm{C} / \mathrm{S}$ & $2002 . \mathrm{Q} 1$ & $-8.89 * * *$ & $-10.46^{* * *}$ & $-100.17 * * *$ \\
\hline
\end{tabular}

*** implies significance at the $1 \%$ level. For C/S Model, critical values for $A D F^{*}$ and $Z_{t}^{*}$ are $-6.92,-6.41$ and -6.17 at the $1 \%, 5 \%$ and $10 \%$ significance levels; while critical values for $Z_{\propto}^{*}$ are $-90.35,-78.52$ and -75.56 at the $1 \%, 5 \%$ and $10 \%$ significance levels, respectively [obtained from Gregory and Hansen (1996)].

\section{Results of DOLS Long-Run Estimations}

Following the testing of cointegration between the variables, long-run coefficients are estimated. The long-run coefficients estimated by DOLS methodology are given in Table 4.

Table 4

Long-Run Coefficients Estimated by Stock and Watson (1993)

\begin{tabular}{lccc}
\hline Variable & Coefficient & Standard Error & $t$-statistic \\
\hline Intercept & $-1.119^{* * *}$ & 0.333 & -3.358
\end{tabular}




\begin{tabular}{lccc}
$T A N$ & $0.165 * * *$ & 0.133 & 1.235 \\
$L E V$ & $0.379 * *$ & 0.177 & 2.138 \\
$L I Q$ & $0.522 * * *$ & 0.174 & 2.989 \\
$O E F$ & $0.021 *$ & 0.012 & 1.718 \\
$D$ & 2.116 & 0.415 & 5.093 \\
$D^{*} T A N$ & $-0.653 * * *$ & 0.170 & -3.850 \\
$D^{*} L E V$ & $-1.150 * * *$ & 0.270 & -4.259 \\
$D^{*} L I Q$ & $-0.672 * * *$ & 0.182 & -3.690 \\
$D^{*} O E F$ & $-0.037 * *$ & 0.016 & -2.354 \\
\hline$R^{2}=0.98 ;$ Adj. $R^{2}=0.93$ & & & \\
\hline
\end{tabular}

Note: $* * *, * *$ and * imply significance at the $1 \%, 5 \%$ and $10 \%$ levels, respectively.

Empirical findings indicate that according to the coefficients estimated, all the independent variables tangibility $(T A N)$, leverage $(L E V)$, liquidity $(L I Q)$ and operating efficiency $(O E F)$ (as proxies for asset tangibility, financial leverage, corporate liquidity and operating efficiency, respectively) have statistically significant effects on financial performance (as proxied by return on assets) during the sample period. While the effects of asset tangibility, financial leverage, corporate liquidity and operating efficiency on financial performance have been positive till (and including) the break date of 2002.Q1; these effects all have turned to negative following 2002.Q1. This break date can be associated with severe economic difficulties the Turkish economy has been experiencing since 1990s, and especially with 2001 crisis (later to be discussed in Conclusion).

\section{Conclusion}

This study aims to analyze the effect of asset tangibility on financial performance by also simultaneous considering the effects of other different firm characteristics such as financial leverage, liquidity and operating efficiency (as control variables) in Turkish manufacturing sector with 18 main sectors and 30 sub-sectors covering 1990.Q3 to 2016.Q4. The stationarity of series is tested by Augmented Dickey-Fuller (1981), Kwiatkowski-Phillips-Schmidt-Shin (1992), and Zivot and Andrews (1992) unit root tests. Unit root test results indicate that series are stationary at their first differences. The existence of cointegration relationship among the series and the possibility of existence of any structural breaks is detected by one-break Gregory and Hansen (1996) cointegration test, concluding empirical findings on the existence of cointegration relationship among the series and a break date of 2002.Q1. Finally, to estimate the long run cointegration coefficients that explain the relationships among the series, dynamic ordinary least squares methodology of Stock and Watson (1993) is employed. Findings indicate that asset tangibility has statistically significant effects on financial performance during the entire sample period. Besides, financial leverage, corporate liquidity and operating efficiency as control variables have the same effect on financial performance. While the effects of all independent variables on financial performance have been positive till (and including) the break date of 2002.Q1; these effects all have turned to negative following the break date.

The structural break date estimated by one-break Gregory and Hansen (1996) cointegration test can be associated with severe economic difficulties the Turkish economy has been experiencing since 1990s. Following 1990s, Turkish economy witnessed dramatic turning points. A currency crisis (crash) emerged in 1994 as consequences of huge public sector borrowing requirements and major policy fallacies in financing the deficits. After five years, in August and November 1999, two destructive earthquakes struck the most industrialized part of Turkey, Kocaeli, causing significant negative effects on economy resulting a 3.4\% contraction of gross domain product (GDP) in 1999. While the adverse effects of the earthquake were ongoing, Turkey encountered another crisis on February 19th, 2001 in the form of a virtual raid on foreign currencies. 
The most devastating effect of 2001 crisis was felt in the domestic banking sector. Along with the collapse of this sector, increase in interest rates and devaluation of the Turkish Lira hit the real sector. Turkish economy contracted by 5.7\% in 2001 and GDP level dropped to the level of 1995. However, the contraction was bigger in the manufacturing sector reaching up to $9.4 \%$. In only the first three months of the crisis, 4,146 firms were closed. During 2001 crisis, unemployment rate due to dismissal increased to $16 \%$, compared to $9 \%$ in the year 2000 level and investments came to a standstill (Atabek Demirhan and Ercan, 2018). As previously stated, major events like economic crises, catastrophes, terrorism and pandemics may have influences on the data analyzed and tend to create structural breaks, the still continuing adverse effects of 1994, 1999 and 2001 crises can be seen as possible causes of the estimated break date of 2002.Q1.

The effect of asset tangibility as proxied by tangible assets (i.e. tangible asset investments) on financial performance have been positive till (and including) the break date. This empirical finding can be associated to Rajan and Zingales (1995)'s evidence that tangible asset intensive firms (such as manufacturing sector firms) can reduce agency costs of debt due to ease of collateralization of these assets, and reduced agency costs of debt will result in higher financial performance. However, this positive contribution of tangible assets to financial performance reversed following the break date. The cause may be related to that during 2001 crisis, especially tangible investments in the manufacturing sector came to a standstill. Besides, higher real interest rates (as a result of abrupt rise in overnight interest rate to $2,000 \%$ on 20 February and $4,000 \%$ on 21 February 2001) not only led to a significant weakening of domestic demand and growth, but also sharply increased funding costs of investments.

Similarly, financial leverage, corporate liquidity and operating efficiency proxied by total debt ratio, current ratio and accounts receivable turnover ratio as control variables, respectively, have the same effect on financial performance. The empirical finding related to financial leverage till (and including) the break date of 2002.Q1 can be explained by findings of Stulz (1990), Ang, Cole and Lin (2000), Abor (2007), Güngöraydınoğlu and Öztekin (2011), and Degryse, Goeij and Kappert (2012). The positive effect of financial leverage on financial performance may be result of the disciplinarian impact of higher financial leverage on firm managers' cash flow waste, because higher pressure of leverage (or debtholders) on firm may result in increasing financial performance to generate more cash to pay for debt. The reverse effect observed following the break date can be associated to sharply increasing funding costs as consequence of 2001 crisis.

The effect of corporate liquidity on financial performance is two-fold. Firm with more liquid assets has advantage of converting these assets into cash quickly at any point of time to meet its liabilities and has tendency to be relatively profitable when compared to other companies with lower levels of liquid assets. For the sample period till (and including) the break date, this point of view fits for the empirical finding of the study that corporate liquidity has positive effect on financial performance. Findings of Ghosh and Maji (2003), Muhammad et al. (2012), Ehiedu (2014) and Rehman et al. (2015) confirm this finding. However, high liquidity also means that firm has idle funds tied up in current assets, reducing chance of investing in other potential projects with more profitability. Besides, return on liquid assets should be reinvested in relatively short time periods, as their reinvestment risks are relatively high. The empirical finding of the study following the break date supports this opposite view as similar to empirical findings of Sur et al. (2001), Bardia (2004), Eljelly (2004), Narware (2004) and Saldanlı (2012), pointing the negative effect of corporate liquidity on financial performance.

The positive effect of accounts receivable turnover ratio on financial performance till (and including) the break date can be a consequence of implementing relatively liberal credit policy. As known, such policy stimulates sales due to availability of longer repayment period to customers for product assessment and ease of access to finance for product acquisition. However, following the break date, due adverse effects of 2001 crisis, manufacturing sector may have been forced to implement conservative credit policy with a side-effect of holding excessive working capital investment that eventually lowers financial performance. Empirical findings of Ramachandran and Janakiraman (2009), Sharma and Kumar (2011), and Abuzayed (2012) is similar to finding of this study for the sample period 
till (and including) the break date; while empirical findings of Dong and Su (2010), Lyngstadaas and Berg (2016), and Shrivastava et al. (2017) fit to this study's finding following the break date of 2002.Q1.

This study is subject to some limitations. The findings of the study cannot be generalized to other sectors, as the sample consists of only the manufacturing sector. Besides, the proxies for both dependent and independent variables referred in the research model can be changed with alternate proxies mentioned in the literature. So, further studies can be conducted considering alternate variables with more enlarged samples consisting of different sectors.

\section{References}

Abor, J. (2007). Debt policy and performance of SMEs: Evidence from Ghanaian and South Africa firms. Journal of Risk Finance, 8(4), 364-379.

Abuzayed, B. (2012). Working capital management and firms' performance in emerging markets: The case of Jordan. International Journal of Managerial Finance, 8(2), 155-179.

Acharya, V., Bharath, S. and Srinivasan, A. (2007). Does industry-wide distress affect defaulted firms? Evidence from creditor recoveries. Journal of Financial Economics, 85(3), 787-821.

Almeida, H. and Campello, M. (2007). Financial constraints, asset tangibility, and corporate investment. The Review of Financial Studies, 20(5), 1429-1460.

Andrews, D. and Criscuolo C. (2013). Knowledge-based capital, innovation and resource allocation. OECD Economics Department Working Papers, No. 1046, OECD Publishing, Paris.

Andrews, D. and de Serres, A. (2012). Intangible assets, resource allocation and growth: A framework for analysis. OECD Economics Department Working Papers, No. 989, OECD Publishing, Paris.

Andrews, D., Criscuolo, C. and Gal, P. N. (2016). The best versus the rest: The global productivity slowdown, divergence across firms and the role of public policy. OECD Productivity Working Papers No. 5, OECD Publishing, Paris.

Ang, J. S., Cole, R. A. and Lin, J. W. (2000). Agency costs and ownership structure. Journal of Finance, 55(1), 81-106.

Arltova, M. and Fedorova, D. (2016). Selection of unit root test on the basis of length of the time series and value of AR(1) parameter. Statistika, 96(3), 47-64.

Atabek Demirhan, A. and Ercan, H. (2018). Export behavior of Turkish manufacturing firms under crises. CBRT Working Paper, No: 18/02.

Azadi, M. (2013). The relationship between changes in asset structure and operating earnings in the Tehran Stock Exchange (TSE). Trends in Advanced Science and Engineering, 7(1), 30-34.

Bae, K.-H. and Goyal, V. K. (2009). Creditor rights, enforcement, and bank loans. Journal of Finance, 64(2), 823-860.

Banos-Caballero, S., García-Teruel, P. J. and Martinez-Solano, P. (2012). How does working capital management affect the profitability of Spanish SMEs. Small Business Economics, 9(2), 517529.

Bardia, S. C. (2004). Liquidity management: A case study of steel authority of India Ltd.. The Management Accountant, 39(6), 463-495. 
Berger, A. N. and Udell, G. F. (1990). Collateral, loan quality and bank risk. Journal of Monetary Economics, 25(1), 21-42.

Birch, K. (2016). Rethinking value in the bio-economy: Finance, assetization and the management of value. Science, Technology and Human Values, 42(3), 460-490.

Birhan, M. (2017). Determinants of insurance company profitability in Ethiopia: Case study on the Nile Insurance, Dire Dawa Branch. International Journal of Scientific and Research Publications, 7(6), 761-767.

Black, J., de Meza, D. and Jeffreys, D. (1996). House prices, the supply of collateral and the enterprise economy. Economic Journal, 106(434), 60-75.

Box, G. E. P. and Jenkins (1970). G. M. time series analysis, forecasting and control. San Francisco: Holden-Day.

Campello, M. and Giambona, E. (2013). Real assets and capital structure. Journal of Financial and Quantitative Analysis, 48(5), 1333-1370.

CBRT (2005-2016). The Central Bank of the Republic of Turkey Company Accounts'2005-'2016.

Chang, C., Lee, A. C. and Lee, C. F. (2009). Determinants of capital structure choice: A structural equation modeling approach. Quarterly Review of Economics and Finance, 49(2), 197-213.

Charitou, M. S., Elfani, M. and Lois, P. (2010). The effect of working capital management. Journal of Business and Economics Research, 8(12), 63-68.

Corrado, C., Haskel, J., Jona-Lasinio, C. and Iommi, M. (2016). Intangible investment in the EU and the US before and since the Great Recession and its contribution to productivity growth. EIB Working Papers 2016/08, European Investment Bank, Luxemburg.

Dawar, V. (2014). Agency theory, capital structure and firm performance: Some Indian evidence. Managerial Finance, 40(12), 1190-1206.

De Jong, A., Kabir, R. and Nguyen, T. T. (2008). Capital structure around the world: The roles of firmand country-specific determinants. Journal of Banking and Finance, 32(9), 1954-1969.

Degryse, H., de Goeij, P. and Kappert, P. (2012). The impact of firm and industry characteristics on small firms' capital structure. Small Business Economics, 38(4), 431-447.

Deloof, M. (2003). Does working capital management affect profitability of Belgian firms?. Journal of Business Finance and Accounting, 30(3-4), 573-588.

Demirgüneş, K. (2016). How does pecking order theory explain determinants of corporate cash holdings? Evidence from BIST listed IT and software companies. ICEB2016 2nd International Congress of Economics and Business, "New Economic Trends and Opportunities", Sarajevo/Bosnia and Herzegovina, May 30-June 3, 1472-1483.

Demirgüneş, K. (2016). The effect of liquidity on financial performance: Evidence from Turkish retail industry. International Journal of Economics and Finance, 8(4), 63-79.

Demmou, L., Stefanescu, I. and Arquie, A. (2019). Productivity growth and finance: The role of intangible assets - a sector level analysis. OECD Economics Department Working Papers 1547, OECD Publishing, Paris. 
Derbali, A. (2014). Determinants of performance of insurance companies in Tunisia: The case of Life Insurance. The World Bank Economic Review, 13(2), 379-408.

Devi, A. and Devi, S. (2014). Determinants of firm's profitability in Pakistan. Research Journal of Finance and Accounting, 5(19), 87-92.

Dickey, D. A and Fuller, W. A. (1981). Distribution of the estimators for autoregressive time series with a unit root. Econometrica, 49(4), 1057-1072.

Dickey, D. A. and Fuller, W. A. (1979). Distribution of the estimators for autoregressive time series with a unit root. Journal of the American Statistical Association, 74(366), 427-431.

Dickey, D. A. (1976). Estimation and hypothesis testing in nonstationary time series. Iowa State University Ph.D. Thesis.

Dietrich, D. (2007). Asset tangibility and capital allocation. Journal of Corporate Finance, 13(5), 9951007.

Doguwa, O. E. O., Uyaebo, S. O. Adamu, I. and Bada, A. S. (2014). Structural breaks, cointegration and demand for money in Nigeria. CBN Journal of Applied Statistics, 5(1), 15-33.

Donaldson, G. (1961). Corporate debt capacity: A study of corporate debt policy and the determination of corporate debt capacity. Division of Research, Graduate School of Business Administration, Harvard University, Boston.

Dong, H. P. and Su, J. T. (2010). The relationship between working capital management and profitability: A Vietnam case. International Research Journal of Finance and Economics, 49(1), 62-71.

Dong, Y. L., Charles K. Y. and Cai, D. (2012). What drives fixed asset holding and risk-adjusted performance of corporates in China? An empirical analysis. International Real Estate Review, 15(2), 141-164.

Downes, J. and Goodman, J. E. (2003). Finance and investment handbook. $6^{\text {th }}$ Edition, New York, Barron's Educational Series Inc.

Dyckman, T. R., Dukes, R. E. and Davis, C. J. (1992). Intermediate accounting. Revised Edition, Homewood IL: Irwin, Inc.

Ehiedu, V. C. (2014). The impact of liquidity on profitability of some selected companies: The financial statement analysis (FSA) approach. Research Journal of Finance and Accounting, 5(5), 81-90.

Eljelly, A. M. A. (2004). Liquidity-profitability trade-off: An empirical investigation in an emerging market. International Journal of Commerce and Management, 14(2), 48-61.

Elliot, G., Rothenberg, T. J. and Stock, J. H. (1996). Efficient tests for an autoregressive unit root. Econometrica, 64(4), 813-836.

Engle, R. F. and Granger, C. (1987). Cointegration and error correction, representation, estimation and testing. Econometrica, 55(2), 251-276.

Eric, K. B., Samuel, A. and Victor, C. L. (2013). Determinants of profitability of insurance firms in Ghana. International Journal of Business and Social Research, 3(3), 43-50. 
Esteve, V. and Requena, F. (2006). A co-integration analysis of car advertising and sales data in the presence of structural change. International Journal of Economics of Business, 13(1), 111-128.

Falope, O. I. and Ajilore, O. T. (2009). Working capital management and corporate profitability: Evidence from panel data analysis of selected quoted companies in Nigeria. Research Journal of Business Management, 3(3), 73-84.

Ghosh, S. K. and Maji, S. (2003). Utilization of current assets and operating profitability: An empirical study on cement and tea industries in India. Indian Journal of Accounting, 34(1), 81-91.

Glynn, J., Perera, N. and Verma, R. (2007). Unit root tests and structural breaks: A survey with applications. Revista de Metodos Cuantitativos para la Economia y la Empresa, 3, 63-79.

Gregory, A. W. and Hansen. B. E. (1996). Residual-based tests for cointegration in models with regime shifts. Journal of Econometrics, 70(1), 99-126.

Grossman, S. J. and Hart, O. D. (1982). Corporate financial structure and managerial incentives. The Economics of Information and Uncertainty, National Bureau of Economic Research, Chicago, IL.

Güngöraydınoğlu, A. and Öztekin, Ö. (2011). Firm-and country-level determinants of corporate leverage: Some new international evidence. Journal of Corporate Finance, 17(5), 1457-1474.

Hall, G. C., Hutchinson, P. J. and Michaelas, N. (2004). Determinants of the capital structures of European SMEs. Journal of Business Finance and Accounting, 31(5-6), 711-728.

Hart, O. and Moore, J. (1994). A theory of debt based on the inalienability of human capital", The Quarterly Journal of Economics, 109(4), 841-879.

Haskel, J., and Westlake, S. (2017). Capitalism without capital: The rise of the intangible economy. Princeton University Press, USA.

Himmelberg, C. P. and Petersen, B. C. (1994). R\&D and internal finance: A panel study of small firms in high-tech industries. Review of Economics and Statistics, 76(1), 38-51.

Holmstrom, B. and Tirole, J. (1997). Financial intermediation, loanable funds, and the real sector. Quarterly Journal of Economics, 112(3), 663-691.

IFRS (2018). Conceptual Framework for Financial Reporting. March.

IRS (1994-2005). Internal Revenue Service (IRS) Reports on Returns of Active Corporations, 19942005. <https://www.irs.gov/statistics/soi-tax-stats-returns-of-active-corporations-table-1.

Johansen, S. (1991). Estimation and hypothesis testing of co-integration vectors in Gaussian vector autoregressive models. Econometrica, 59(6), 1551-1580.

Jose, M., Lancaster, C. and Stevens, J. (1996). Corporate returns and cash conversion cycles. Journal of Economics and Finance, 20(1), 33-46.

Khan, T., Shamim, M. and Goyal, J. (2018). Panel data analysis of profitability determinants: Evidence from Indian telecom companies. Theoretical Economics Letters, 8(5), 3581-3593.

Kocaman, M., Altemur, N., Aldemir, S. and Karaca, S. S. (2016). The factors affecting economics profitability: A case study of ISO 500 industry firms. Mustafa Kemal University Journal of Social Sciences Institute, 13(35), 320-332. 
Koralun-Bereznicka, J. (2013). How does asset structure correlate with capital structure? - Crossindustry and cross-size analysis of the EU countries. Universal Journal of Accounting and Finance, 1(1), 19-28.

Korkmaz, Ö. and Karaca, S. S. (2014). Financial determinants of firm profitability in manufacturing firms and application on BIST manufacturing firms. Ege Academic Review, 14(1), 21-29.

Kotsina, S. and Hazak, A. (2012). Does investment intensity impact company profitability? A crosscountry empirical study. Proceedings from the $2^{\text {nd }}$ International Conference on Economics, Trade and Development, IPEDR, Vol. 36, IACSIT Press, Singapore.

Kraus, A. and Litzenberger, R. H. (1973). A state-preference model of optimal financial leverage. Journal of Finance, 28(4), 911-922.

Kwiatkowski, D., Phillips, P. C. B., Schmidt, P. and Shin, Y. (1992). Testing the null hypothesis of stationary against the alternative of a unit root: how sure are we that economic time series have a unit root?. Journal of Econometrics, 54(1-3), 159-178.

Lei, J., Qiu, J. and Wan, C. (2018). Asset tangibility, cash holdings, and financial development. Journal of Corporate Finance, 50(C), 223-242.

Liberti, J. M. and Sturgess, J. (2016). The anatomy of a credit supply shock: Evidence from an internal credit market. Journal of Financial and Quantitative Analysis, 53(2), 547-579.

Lu-Andrews, R. and Yu-Thompson, Y. (2015). CEO inside debt, asset tangibility, and investment. International Journal of Managerial Finance, 11(4), 451-479.

Lyandres, E. and Palazzo, B. (2016). Cash holdings, competition, and innovation. Journal of Financial and Quantitative Analysis, 51(6), 1823-1861.

Lyngstadaas, H. and Berg, T. (2016). Working capital management: Evidence from Norway. International Journal of Managerial Finance, 12(3), 295-313.

MacKinnon, J. G. (1991). Critical values for cointegration tests. In Engle, R. F. and Granger, C. W. J. (Eds.), Long Run Economic Relationships (pp. 267-276). Oxford University Press.

Mateev, M., Poutziouris, P. and Ivanov, K. (2013). On the determinants of SME capital structure in central and eastern Europe: A dynamic panel analysis. Research in International Business and Finance, 27(1), 28-51.

McConnell, J. J. and Servaes, H. (1995). Equity ownership and the two faces of debt. Journal of Financial Economics, 39(1), 131-157.

Mehari, D. and Aemiro, T. (2013). Firm specific factors that determine insurance companies' performance in Ethiopia. European Scientific Journal, 9(10), 88-96.

Modigliani, F. and Miller, M. H. (1963). Corporate income taxes and the cost of capital: A correction. The American Economic Review, 53(3), 433-443.

Mohamad, N. E. A. and Saad, N. M. (2010). Working capital management: The effect of market valuation and profitability in Malaysia. International Journal of Business and Management, $5(11), 140-148$. 
Muhammad, M., Jan, W. U. and Ullah K. (2012). Working capital management and profitability: An analysis of firms of textile industry of Pakistan. Journal of Managerial Sciences, 6(2), 155-165.

Mun, S. G. and Jang, S. (2015). Working capital, cash holding, and profitability of restaurant firms. International Journal of Hospitality Management, 48(1), 1-11.

Musah, M., Kong, Y. and Osei, A. A. (2019). The nexus between asset tangibility and firms' financial performance: A panel study of non-financial firms listed on the Ghana Stock Exchange (GSE). European Academic Research, 12(1), 450-474.

Mwaniki, G. and Omagwa, J. (2017). Asset structure and financial performance: A case of firms quoted under commercial and services sector at the Nairobi Securities Exchange, Kenya. Research Journal of Finance and Accounting, 8(4), 192-200.

Myers, S. C. and Majluf, N. S. (1984). Corporate financing and investment decisions when firms have information that investors do not have. Journal of Financial Economics, 13(2), 187-221.

Myers, S. C. (1984). The capital structure puzzle. Journal of Finance, 39(3), 575-592.

Myers, S. C. (2001). Capital structure. Journal of Economic Perspectives, 15(2), 81-102.

Ng, S., and Perron, P. (1995). Unit root tests in ARMA models with data-dependent methods for the selection of the truncation lag. Journal of the American Statistical Association, 90(429), 268281.

Ng, S., and Perron, P. (2001). Lag length selection and the construction of unit root tests with good size and power. Econometrica, 69(6), 1519-1554.

Nobanee, H., Abdullatif, M. and AlHajjar, M. (2011). Cash conversion cycle and firm's performance of Japanese firms. Asian Review of Accounting, 19(2), 147-156.

Nunes, P. J. M., Serrasqueiro, Z. M. and Sequeira, T. N. (2009). Profitability in Portuguese service industries: A panel data approach. The Service Industries Journal, 29(5), 693-707.

Okwo, I. M., Okelue, U. D. and Nweze, A. U. (2012). Investment in fixed assets and firm profitability: Evidence from the Nigerian brewery industry. European Journal of Business and Management, 4(20), 10-17.

Olatunji, T. E. and Tajudeen, A. A. (2014). Investment in fixed assets and firm profitability: Empirical evidence from the Nigerian banking sector. Asian Journal of Social Sciences and Management Studies, 1(3), 78-82.

Perron, P. (1989). The Great Crash, the Oil-Price shock and the unit root hypothesis. Econometrica, 57(6), 1361-1401.

Phillips, P. C. B. and Perron, P. (1988). Testing for a unit root in a time series regression. Biometrika, 75(2), 335-346.

Pratheepan, T. (2014). A panel data analysis of profitability determinants: empirical results from Sri Lankan manufacturing companies. International Journal of Economics, Commerce and Management, 2(12), 1-9.

Rajan, R. G. and Zingales, L. (1995). What do we know about capital structure? Some evidence from international data. Journal of Finance, 50(5), 1421-1460.

Ramachandran, A. and Janakiraman, M. (2009). The relationship between working capital management efficiency and EBIT. Managing Global Transitions, 7(1), 61-74. 
Rehman, M. Z., Khan M. N. and Khokhar, I. (2015). Investigating liquidity-profitability relationship: Evidence from companies listed in Saudi Stock Exchange. Journal of Applied Finance and Banking, 5(3), 159-173.

Reyhani, A. G. (2012). The investigation of effect of asset structure on performance of accepted companies of Tehran Stock Exchange. Journal of Basic and Applied Scientific Research, 2(2), 1086-1090.

Rivard, R. J. and Thomas, C. R. (1997). The effect of interstate banking on large bank holding company profitability and risk. Journal of Economic and Business, 49(1), 61-76.

Şamiloğlu, F. and Demirgüneş, K. (2008). The effect of working capital management on firm profitability: Evidence from Turkey. International Journal of Applied Economics and Finance, $2(1), 44-50$.

Saravanan, P., Sivasankaran, N., Srikanth, M. and Shaw, T. S. (2017). Enhancing shareholder value through efficient working capital management: An empirical evidence from India. Finance India, 31(3), 851-871.

Sharma, A. K. and Kumar, S. (2011). Effect of working capital management on firm profitability: Empirical evidence from India. Global Business Review, 12(1), 159-173.

Shin, H. H. and Soenen, L. (1998). Efficiency of working capital management and corporate profitability. Financial Practice and Education, 8(2), 37-45.

Shleifer, A. and Vishny, R. W. (1992). Liquidation values and debt capacity: A market equilibrium approach. Journal of Finance, 47(4), 1343-1366.

Shrivastava, A., Kumar, N. and Kumar, P. (2017). Bayesian analysis of working capital management on corporate profitability: Evidence from India. Journal of Economic Studies, 44(4), 568-584.

Stock, J. H. and Watson, M. W. (1993), A simple estimator of cointegrating vectors in higher order integrated systems. Econometrica, 61(4), 783-820.

Stulz, R. (1990). Managerial discretion and optimal financing policies. Journal of Financial Economics, 26(1), 3-27.

Sur, D., Biswas, J. and Ganguly, P. (2001). Liquidity management in Indian private sector enterprises: A case study of Indian primary aluminum producing industry. Indian Journal of Accounting, $32,8-14$.

Thum-Thysen, A., Voigt, P., Bilbao-Osorio, B. and Maier, C. (2019). Investment dynamics in Europe: Distinct drivers and barriers for investing in intangible versus tangible assets?. Structural Change and Economic Dynamics, 51(C), 77-88.

Titman, S., and Wessels, R. (1988). The determinants of capital structure choice. Journal of Finance, 43(1), 1-19.

Vintila, G. and Nenu, E. A. (2015). An analysis of determinants of corporate financial performance: Evidence from the Budapest stock exchange listed companies. International Journal of Economics and Financial Issues, 5(3), 732-739.

Wang, Y. J. (2002). Liquidity management, operating performance, and corporate value: Evidence from Japan and Taiwan. Journal of Multinational Financial Management, 12(2), 159-169.

Zivot, E. and Andrews, D. (1992). Further evidence of Great Crash, the Oil-Price shock and unit root hypothesis. Journal of Business and Economic Statistics, 10(3), 251-270. 


\section{Genișletilmiş Özet}

\section{Giriş}

1980li yılların başlarından itibaren, dünya genelinde firmaların varlık yatırımlarına yönelik bakış açılarının giderek değişmeye başladığı ve maddi varlık yatırımlarından çok, maddi olmayan varlık yatırımlarına doğru bir yönelimin olduğu açık bir biçimde gözlemlenmektedir. Türkiye Cumhuriyet Merkez Bankası (TCMB) Sektör Bilançoları istatistikleri incelendiğinde, söz konusu yönelimin Türkiye'de faaliyet gösteren üretim işletmeleri için de geçerli olduğunu söylemek mümkündür. Ancak, dünya ekonomilerinde maddi olmayan varlık yatırımlarının artan önemine karşın, bu varlıkların finansal performans üzerindeki etkileri tartışmaya açı bir konudur. Maddi olmayan varlık yatırımları, maddi varlık yatırımları ile kıyaslandıklarında, daha riskli olabilmekte ve kaldıraç etkisi yaratmada -madditeminat olarak yeterince kullanılamamaktadır. Bilindiği üzere, maddi varlık yatırımları ise nispeten garantili olduklarından, firmaların krediye erişimde kullandıkları başlıca teminat kaynağıdır. Ayrıca, aktif toplamı içindeki içinde maddi varlık yoğunluğu firmanın toplam borçlanma kapasitesinin de önemli bir göstergesidir. Sonuç itibariyle, nispeten fazla maddi varlığa sahip firmaların fonlama maliyetleri daha düşük, finansal performansları da daha yüksek olabilmektedir.

Bu çalışmada; 1990.Q3-2016.Q4 dönemini kapsayan zaman serisi verisi kullanılarak Türkiye'de imalat sanayi sektöründe, maddi varlık yatırımlarının finansal performans üzerindeki olası etkisinin araştırılması amaçlanmaktadır.

\section{Literatür İncelemesi}

Varlık yapısı ve finansal performans arasındaki ilişkiyi Donaldson (1961) tarafından ortaya atılan ve sonrasında Myers (1984) ile Myers ve Majluf (1984) tarafindan geliştirilen finansman hiyerarşisi (pecking order) teorisi ve Kraus ve Litzenberger (1973) tarafından önerilen dengeleme (tradeoff) teorisi ile açıklamak mümkündür. Finansman hiyerarşisi teorisi, maddi varlıkların sermaye yapısı üzerindeki etkisini borçlanma bağlamında ele almaktadır, çünkü söz konusu varlıklardan borç finansmanında -maddi- teminat olarak faydalanılmaktadır. Almeida ve Campello (2007), Campello ve Giambona (2013) ve Koralun-Bereznicka (2013) tarafindan yapılan çalışmalardan elde edilen bulgular, varlık teminatlandırmasının sermaye yapısının bir belirleyicisi olarak, firmanın -nispeten düşük maliyetli- borç finansmanı imkanını artırdığını, buna bağlı olarak da finansal perfromansının artmasına neden olduğunu göstermektedir.

Dengeleme teorisi ise vergi kalkanı etkisinin maksimum ve borçlanmadan kaynaklanan iflas maliyetlerinin minimum olduğu noktada optimal sermaye yapısının varlığını savunmaktadır. Myers (2001)'e göre; borç finansmanı vergi etkisi yaratmakta ve bu etkiye bağlı olarak faiz ödemelerinin vergiden düşülmesi neticesinde, borcun gerçek maliyeti belirlenen faiz oranından daha düşük olmaktadır. Bu bağlamda, her ne kadar finansman hiyerarşisi teorisindeki kadar açık olmasa bile, dengeleme teorisi firmanın belirli bir noktaya kadar borçlanmanın yaratacağı vergi kalkanı etkisinden faydalanmasına imkân vermektedir.

Varlık yapısı ve finansal performans arasındaki ilişkiyi irdeleyen literatür oldukça kapsamlı olup, elde edilen ampirik bulgular karışıktır. Bu bağlamda, Dong, Charles ve Cai (2012), Reyhani (2012), Azadi (2013), Mehari ve Aemiro (2013), Olatunji ve Tajudeen (2014), Birhan (2017) ile Khan, Shamim and Goyal (2018) tarafından yapışan çalışmalarda varlık yapısı içinde maddi varlıkların finansal performansı pozitif yönde etkilediği bulgusuna ulaşılırken; Eric, Samuel ve Victor (2013), Pratheepan (2014) ile Vintila ve Nenu (2015) söz konusu ilişkinin negatif yönlü olduğunu tespit etmişlerdir. 


\section{Yöntem ve Ampirik Bulgular}

Araştırma modelinde yer alan serilerin durağanlık düzeyleri Genişletilmiş Dickey-Fuller (1981), Kwiatkowski-Phillips-Schmidt-Shin (1992) ve Zivot ve Andrews (1992) birim kök testleri kullanılarak tespit edilmektedir. Seriler arasındaki uzun dönemli ilişkiler tek yapısal kırılmaya izin veren Gregory ve Hansen (1996) eşbütünleşme testi ile incelenmektedir. Gregory ve Hansen (1996) eşbütünleşme testi sonuçları; finansal performans ve diğer bağımsız değişkenler (maddi varlık yapısı, kaldıraç, likidite ve faaliyet etkinliği değişkenleri) arasında uzun dönemli ilişkinin varlığını göstermektedir. Son olarak, aralarında eşbütünleşme ilişkisi tespit edilen değişkenler arasındaki uzun dönemli ilişkileri gösteren katsayıların tahminlemesinde, yapısal kırılmaların kukla değişken olarak analize dâhil edilebildiği Stock ve Watson (1993) tarafından geliştirilen dinamik en küçük kareler yöntemi kullanılmaktadır. Dinamik en küçük kareler tahmincisi sonuçlarına göre; maddi varlık yapısı, finansal kaldıraç, likidite ve faaliyet etkinliği değişkenlerinin finansal performansa karşı uzun dönem katsayıları istatistiksel olarak anlamlıdır. Kırılma tarihi (2002.Q1) de dahil olmak üzere, bu tarihe kadar, bağımsız değişkenlerin tamamının finansal performansı olumlu yönde etkilediği görülürken; söz konusu etkileşim kırılma tarihi sonrasında negatife dönmektedir.

\section{Sonuç}

1990.Q3-2016.Q4 dönemini kapsayan zaman serisi verisi kullanılarak Türkiye'de imalat sanayi sektöründe, maddi varlık yatırımlarının finansal performans üzerindeki olası etkisinin araştırıldığı bu çalışma sonucunda; araştırma modelinin açıklayıcı değişkenleri olan maddi varlık yapısı, finansal kaldıraç, likidite ve faaliyet etkinliği değişkenlerinin kırılma tarihi olan 2002.Q1 de dahil olmak üzere bu döneme kadar finansal performansı olumlu yönde etkilediği görülürken; söz konusu etkileşimin kırılma tarihi sonrasında negatife döndügü görülmektedir.

Söz konusu kırılma tarihinin nedeninin 2001 krizinin yarattı̆g ekonomik yıkım olduğunu söylemek mümkündür. 2001 krizinin en yıkıcı etkilerinin bankacılık sektöründe hissedildiği açıtır. Kriz ve kriz sonrası dönemde; bankacılık sektörünün çökmesi ile birlikte, faiz oranlarında meydana gelen aşırı artış ve TL'nın devalüe edilmesi sonucunda Türkiye ekonomisinde ve özellikle de reel sektörde önemli ölçüde daralma yaşanmıştır. 2001 yılında Türkiye ekonomisi $\% 5,7$; reel sektör ise $\% 9,4$ oranında daralmış ve krizin ilk üç ayında 4.146 işletme kapanmak zorunda kalmıştır.

Varlık yapısı (maddi duran varlıklar) ve finansman performans arasındaki ilişki bağlamında, kırılma tarihine bağlı olarak elde edilen iki farklı bulguyu daha önceki çalışmalardan elde edilen ampirik bulgular çervesinde açıklamak mümkündür. 